\title{
IZOBRAŽEVANJE ZA TOLERANCO, SOŽITJE IN SKUPNI RAZVOJ
}

Minilo je več kot leto dni od grozovitega masakra Andreasa Breavika na norveškem otoku Utoja. Po prvem šoku, ko se je celotno dogajanje povezovalo predvsem s psihološkimi značilnostmi in osebnostnimi deformacijami oziroma neprištevnostjo morilca, se danes vse bolj pojavljajo racionalni pomisleki, vprašanja o kavzalnosti dejanja in o njegovi morebitni povezanosti z družbeno izoliranostjo, religijskim, etničnim in političnim fundamentalizmom ter ekstremizmom. Pri iskanju razlogov je zanimivo, neobičajno in nepričakovano predvsem to, da se je vse skupaj zgodilo v družbi, ki slovi po visoki kakovosti življenja, odprtosti in inkluzivističnem potencialu. Tudi tragedija na bostonskem maratonu je pretresla svet, čeprav se samomorilski napadi v Iraku in Afganistanu dogajajo vsak dan.

Dejstvo je, da se taki in drugačni tragični primeri $v$ današnjem času dogajajo tako $v$ zahodnem svetu, ki naj bi se odlikoval z dolgo tradicijo demokracije, upoštevanjem človekovih pravic in strpnostjo, kot tudi na $v z h o d u, v$ državah, kjer tudi obstajajo in veljajo določeni vrednostni sistemi. A neodvisno od odprtosti oziroma zaprtosti sistema so skupna značilnost destruktivnih pojavov ne le mentalna odstopanja, ampak tudi ekstremizem, netolerantnost, izključevanje in sovraštvo.

Seveda obstajajo tudi nasprotne tradicije. $V$ Izraelu, tudi na palestinskih območjih, že dolgo delujejo skupine študentov, mladih Judov in Palestincev, ki skupaj organizirajo kampanje za preprečevanje nasilja in si prizadevajo za medetnično kohabitacijo.
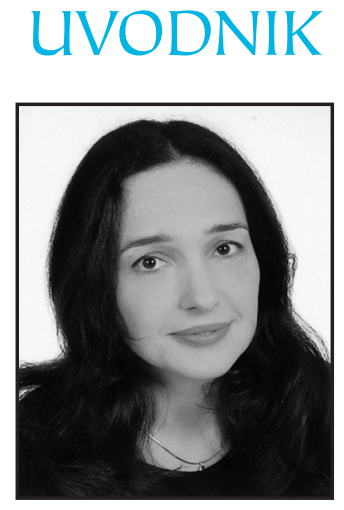

Podlaga teh kampanj je skupna tradicija mirnega sobivanja Arabcev in Judov.

Prof. Robert Hunt s Perkinsove teološke šole $v$ Dallasu je naredil študijo primera na podlagi izkušenj petletnega projekta o dialogu študentov kristjanov, muslimanov, budistov, hinduistov in judov v majhnih skupinah. Pri evalvaciji so udeleženci opozorili, da so se med izvajanjem projekta pokazali kulturni konflikti, getoizacija nekaterih skupin, nefunkcionalnost kanalov kulturne koeksistence. Kljub temu je boljša obveščenost o religijskih in kulturnih prvinah pripomogla $k$ boljšemu razumevanju skupnih vrednot, humanistično-etičnih ciljev in prepričanj. Hunt ugotavlja, da imajo ljudje ne glede na kulturne razlike in konflikte $v$ svetu ter prizadevanje po afirmaciji lastnih vrednot in ritualov - neverjetno sposobnost za usklajevanje in integracijo teh razlik in značilnosti $v$ širši sistem. Medreligijski in medkulturni dialog ter razumevanje, skupaj $z$ izobraževanjem, globalizacijo množičnih komunikacij ter zmanjševanjem razvojnih diskrepanc $v$ svetu, močno pripomore $k$ ustvarjanju novih kulturnih tradicij in vrednot. V izhodišču tega procesa je podpiranje tolerantnosti, sprejemanje različnosti, multikulturalizem in inkluzivnost.

Tolerantnost, ki je v slovarjih najpogosteje opredeljena kot prizanesljivost, strpnost in sprejemanje veljavnosti drugačnih oziroma drugače mislečih, zlasti pri religijskih, političnih in etičnih vprašanjih, ni le politična ali pravna kategorija, temveč je ozko povezana $z$ emancipatornim in aktivacijskim potencialom izobraževanja, predvsem izobraževanja odraslih. Erich 
Fromm denimo poudarja povezanost med sistemom izobraževanja odraslih in premagovanjem občutka družbene odtujenosti, kar navezuje na humanistični razvoj in solidarnost. Pri tem je pomembno poudariti, da je toleranca $v$ svojem bistvu individualni proces oziroma drža in da vsak posameznik subjektivno sprejema videnja in ravnanja drugih. Tudi resnica je relativna in mitična. Toda v Evropi in svetu obstaja konsenz o visoki stopnji povezanosti med demokratično in tolerantno družbeno klimo ter izobraževanjem odraslih, kar je poudarjeno ob različnih priložnostih, srečanjih in $v$ mednarodnih dokumentih ter smernicah Unesca. Empirični dokazi namreč potrjujejo, da več ko ljudje vedo drug o drugem, bolj so pripravljeni sprejemati in spoštovati različnosti/drugačnosti, živeti drug ob drugem in imajo manj predsodkov (A Contribution to Dialogue or Factor of Conflict in Transforming Societies of The European Countries - REDCo). V tem kontekstu je zelo pomembna tudi vloga ustanov - izobraževalnih, kulturnih, raziskovalnih, nevladnih ..., ki podpirajo učno dejavnost in ustvarjajo prostor za spodbujanje takih vrednot.

Mnoge dosedanje analize in raziskave so pokazale, da je v skandinavskih državah stopnja tolerance hkrati z obstojem predispozicij za sprejemanje stališč drugih in drugače mislečih relativno visoka. Te države imajo dolgo tradicijo izobraževanja odraslih in ustanove, ki zagotavljajo priložnosti za učenje in podoben izhodiščni položaj vsem prebivalcem ter podpirajo in spodbujajo udejstvovanje ljudi, pri čemer so v izhodišču in načinu izvedbe precej demokratične. V ozadju pa je močna civilna družba, ki postaja pomembno prizorišče za prakticiranje tolerance in demokracije.

$V$ obdobju gospodarske in družbene krize se nekateri družbeni koncepti redefinirajo, postavljajo se nove vrednostne orientacije, oblikuje določena etična drža, medgeneracijska solidarnost in nastajajo temelji za določeno intelektualno ter duhovno kakovost življenja. Analitiki in oblikovalci družbenega dogajanja se sprašujejo, kakšno družbo si želimo, kakšne naj bodo prednostne naloge razvoja, razmerje med posameznimi družbenimi podsistemi, odnos do neznanega drugega ter kako zagotoviti možnost za samouresničevanje $v$ pluralni družbi z visoko stopnjo socialne integracije. $V$ tem kontekstu delovanja se postavlja tudi vprašanje o vlogi in položaju izobraževanja odraslih, o njegovi institucionalnosti in $\mathrm{ka}$ drovski podprtosti, o priložnostih, ki jih bo ali ne bo imelo pri sooblikovanju prihodnje družbe. Ponovno se postavljajo vprašanja o mejah med javnim in zasebnim, splošnim, širšim in specifičnim, med učinkovitim, koristnim in pravičnim ... Očitno je, da ima gospodarska kriza dolgoročne posledice, ki ne segajo samo $v$ gospodarstvo, finance in socialo, temveč tudi v človekove vrednote, moralo, intelektualno, duhovno kakovost življenja in osebnosti. Po oceni dr. Krajnčeve so sekundarne in manj vidne posledice dolgotrajnejše.

Zdaj, ko se rekonceptualizirajo temelji, izhodišča in smernice nadaljnjega razvoja celotne izobraževalne sfere, je treba še bolj jasno opredeliti pomen, vlogo in status njegovih podsistemov $v$ družbi, prispevek pri vključevanju najbolj prikrajšanih, pri emancipaciji in ustvarjanju priložnosti za osebni, gospodarski in širši razvoj ter kakovost bivanja. Navsezadnje je treba oblikovati etično držo do drugačnih in drugače mislečih. Angleški ekonomist in esejist Walter Bagehot je $v$ drugi polovici 19. stoletja zapisal tudi to: „Če je neko ljudstvo sposobno odprte komunikacije, potem je sposobno tudi mentalne tolerance in sožitja. "Znani Herbert Marcuse je v nekaterih svojih delih iz 60. let razložil, da cilj tolerantnosti ni resničnost položaja večine, temveč resničnost manjšin skozi večine. 
Po grozovitem dogodku je norveški premier Jens Stoltenberg na vprašanje o tem, kako bo Norveška ravnala v prihodnje - ali se bo odzvala z zapiranjem, represijo, zmanjševanjem pravic ali z odprtostjo, odgovoril zelo drugače, kot bi nekateri evropski politiki: »Na nasilje bomo odgovorili z večjo odprtostjo, demokracijo, tolerantnostjo."

Mag. Jasmina Mirčeva

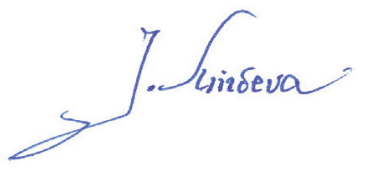

